\title{
Effect of Integration of Seed Bio-priming and Inorganic Fertilization on Soil Physico-chemical Properties of Sunflower (Helianthus annuus L.)
}

\section{O. Siva Devika* and Amitava Rakshit}

Department of Soil Science and Agricultural Chemistry, Institute of Agricultural Sciences, Banaras Hindu University, Varanasi, Uttar Pradesh, India

"Corresponding author: shivadevika990@gmail.com (ORCID ID: 0000-0002-9738-9328)

Paper No. 887

Received: 06-01-2021

Revised: 25-02-2021

Accepted: 10-03-2021

\begin{abstract}
Conventional agricultural practices rely on the immense application of agrochemicals that show detrimental effects on soil biota. Negative impacts on soil microbiota and enzymes that involve in nutrient cycles hinder nutrient availability. Application of plant growth-promoting microbes such as Trichoderma spp. can evade these hurdles by improving soil biodiversity and performance of the crop. A pot culture experiment was conducted during two consecutive years (2018 and 2019) to figure out the effect of different doses of fertilizers and seed bio-priming with Trichoderma asperellum BHUT8 in sunflower (PAC334) on soil chemical properties. Results showed that the initial soil reaction was slightly alkaline that tend towards neutral with seed bio-priming. The electrical conductivity of soil in both seasons varied randomly among imposed treatments. Soil cation exchange capacity, which permits the soil to hold all essential nutrients, was enhanced $4 \%$ with the supply of $70 \%$ recommended dose of fertilizer and seed bio-priming. Soil available nitrogen, phosphorus, and potassium were found maximum in the treatments supplied with Trichoderma through seed bio-priming. Inoculation of Trichoderma showed positive effects on soil chemical properties and reduced the requirement of inorganic fertilizers.

Highlights

( The obtained results of biopriming-inorganic fertilization on the growth parameters and yield of sunflower recommend their use as an alternative tool to reduce chemical fertilizers.

(0) The use of biopriming inorganic fertilization minimizes negative impacts on natural resources and caused an obvious increase in microbial activity, which is manifested by increased NPK content in the soil.
\end{abstract}

Keywords: Soil reaction, inoculum, recommended dose of fertilizer (RDF), available nutrients.

In the wake of the green revolution, concerned with crop production, the use of agrochemicals has been increased, which further magnified the impacts. Agro-chemicals contaminate soil, water, vegetation, toxic to beneficial insects, and non-target plants that decline populations of beneficial microorganisms in the soil, also affect humans by causing cancer and other chronic health effects as a majority of foods have detectable levels of chemical residues. Modern agricultural practices that use huge quantities of inputs have deleterious effects on human health, environment, and soil quality as it badly affects soil physical, chemical, and biological properties (Arriaga et al. 2017). The physical and chemical properties of soil are also affected due to human activities such as improper irrigation practices, disproportionate application of chemical fertilizers,

How to cite this article: Devika, O.S. and Rakshit, A. 2021. Effect of Integration of Seed Bio-priming and Inorganic Fertilization on Soil Physico-chemical Properties of Sunflower (Helianthus annuus L.). IJAEB, 14(1): 111-117.

Source of Support: None; Conflict of Interest: None 
and carbon losses (Aulakh and Sidhu 2015). In the soil system, dissolved ions are accumulated because of severe evaporation losses and fertilizer use that leads to nutritional imbalance, decrease in soil permeability, and other indirect losses (Visconti and Paz 2016). Redundant use of chemical fertilizers causes instability of soil ecosystem and other complications such as groundwater contamination and environmental effects. In developing countries, adverse health effects are noticed in farmers due to exposure to agro-chemicals (Zhang et al. 2018). Disproportionate use of agrochemicals can be avoided by adopting sustainable agricultural practices such as the application of microorganisms, which is eco-friendly and economical too. Microbial application through seed needs only a small quantity of inoculum, also improves plant growth and yield (Rocha et al. 2019). Among all methods of microbial application, the appropriate technique is through seed bio-priming, which is the combination of two processes, i.e., seed hydration and microbial inoculation by beneficial microorganism (Rakshit et al. 2015; Singh et al. 2018; Sarkar et al. 2018; Rakshit 2019; Sarkar and Rakshit 2021). This study is conducted with an objective to find out the effect of seed bio-priming on soil chemical properties with test crop sunflower, and the microbe selected for study is Trichoderma asperellum.

\section{MATERIALS AND METHODS}

\section{Seed bio-priming}

Seed bio-priming was carried out with micro

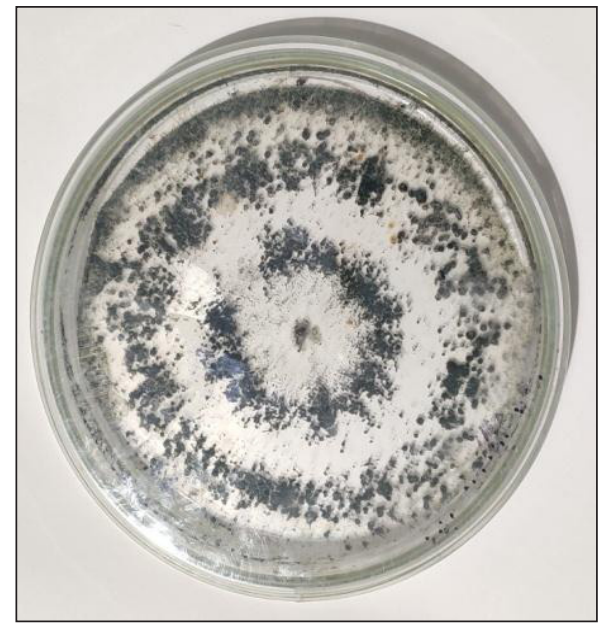

(a) organism Trichoderma asperellum that was cultured on PDA procured from the Department of Mycology and Plant Pathology, Institute of Agricultural Sciences, Banaras Hindu University. Spore count in suspension was maintained at $10^{8} \mathrm{CFU} \mathrm{ml}-1$, and 3-4 drops of tween-20 were added. Sunflower seeds were hydrated for $6 \mathrm{hr}$ followed by surface sterilization with $1 \%$ sodium hypochlorite $(\mathrm{NaOCl})$ solution that was placed in moisture chamber and then incubated for $48 \mathrm{hr}$ after drenching with spore suspension (Fig. 1).

\section{Experimental details}

Pot culture experiment was conducted for two seasons with sunflower (variety: PAC 334) at Department of Soil Science and Agricultural Chemistry, Institute of Agricultural Sciences, Banaras Hindu University, Varanasi $\left(25^{\circ} 20^{\prime} \mathrm{N}\right.$ latitude and $83^{\circ} 01^{\prime} \mathrm{E}$ longitudes). The experimental design was a completely randomized design with four replications. First season and second season experiments were conducted during February second fortnight to may second fortnight in 2018 and 2019, respectively. Treatments imposed were $\mathrm{T}_{1}$ : control, $\mathrm{T}_{2}: 70 \% \mathrm{RDF}, \mathrm{T}_{3}: 80 \% \mathrm{RDF}, \mathrm{T}_{4}: 90 \% \mathrm{RDF}$, $\mathrm{T}_{5}: 100 \%$ RDF (90-50-50), $\mathrm{T}_{6}: 70 \% \mathrm{RDF}+$ Sees biopriming, $\mathrm{T}_{7}: 80 \%$ RDF + Sees bio-priming, $\mathrm{T}_{8}: 90 \%$ $\mathrm{RDF}+$ Sees bio-priming. Initial properties of soil are given in table 1 .

\section{Soil reaction $(\mathrm{pH})$}

Soil reaction was determined by a combined glass

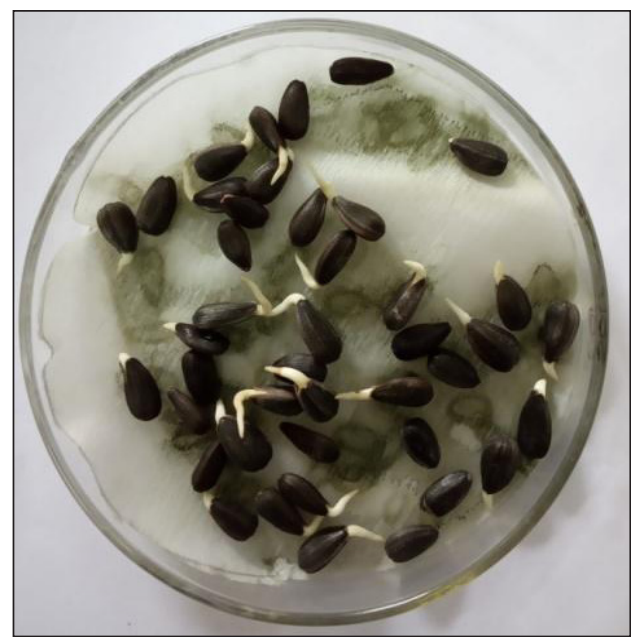

(b)

Fig. 1: (a) Culture of Trichoderma asperellum (b) Bio-primed sunflower seed 
Table 1: Initial properties of experimental soil

\begin{tabular}{llll}
\hline Soil property & Value & Soil property & Value \\
\hline Bulk Density $\left(\mathrm{Mg} \mathrm{m}^{-3}\right)$ & 1.41 & CEC $\left(\mathrm{C} \mathrm{mol}\left(\mathrm{p}^{+}\right) / \mathrm{kg}\right)$ & 30.91 \\
Particle density $\left(\mathrm{Mg} \mathrm{m}^{-3}\right)$ & 2.58 & Organic carbon $\left(\mathrm{g} \mathrm{kg}^{-1}\right)$ & 4.1 \\
Water holding capacity $(\%)$ & 39.4 & Available N $(\mathrm{kg} / \mathrm{ha})$ & 217 \\
Soil Texture & Sandy loam & Available P $(\mathrm{kg} / \mathrm{ha})$ & 16.67 \\
pHw $(1: 2.5)$ & 7.3 & Available K (kg/ha) & 234 \\
EC $(\mathrm{dS} / \mathrm{m})$ & 0.38 & & \\
\hline
\end{tabular}

electrode in 1:2.5 soil water suspension (Jackson, 1973).

\section{Electrical conductivity (EC)}

EC of soil suspension was determined in the same sample used for soil reaction. Reading was taken by using an electrical conductivity bridge in supernatant solution after allowing the suspension to settle down (Jackson, 1973).

\section{Cation Exchange Capacity (CEC)}

Soil samples were saturated with $1 \mathrm{~N}$ sodium acetate $(\mathrm{pH}$ 8.3). The excess sodium acetate was leached out by washing out with $95 \%$ ethanol. Then the adsorbed sodium was displaced with neutral normal ammonium acetate. The concentration of sodium in the leachate was estimated flame photometrically (Bower et al. 1952).

\section{Soil available nitrogen}

Available nitrogen content in soil samples was determined by the alkaline potassium permanganate method (Subbiah and Asija 1956). To the known weight of soil, $\mathrm{KMnO}_{4}$ (oxidizing agent) was added. Nascent oxygen released in the presence of $\mathrm{NaOH}$ oxidizes organic matter, and the released ammonia absorbed in a boric acid of known concentration. The excess is known by the titration method by using a mixed indicator.

\section{Available phosphorus}

Available phosphorus in the soil samples was extracted with $0.5 \mathrm{M} \mathrm{NaHCO}_{3}$ of $\mathrm{pH} \mathrm{8.5,} \mathrm{and}$ the phosphorus in the extract was estimated colorimetrically by an ascorbic acid method using a spectrophotometer at $660 \mathrm{~nm}$ (Watanabe and Olsen 1954).

\section{Available potassium}

Available potassium in soil was extracted using neutral normal ammonium acetate, and potassium in the extract was determined to flame photometrically (Muhr et al. 1965).

\section{Statistical analysis}

Data analysis was done by using Statistical Package for Social Science (SPSS) software (Version 20). $\mathrm{R}$ studio (version 4.0.4) was used for the computation of the correlation matrix.

\section{RESULTS AND DISCUSSION}

\section{Soil reaction}

Pooled data showed that the soil reaction ranged from 7.2 to 7.5 (Fig. 1). During the first season, the highest soil $\mathrm{pH}$ was noticed in control and 100\% RDF (7.4), which was slightly alkaline in reaction. Reduction in soil $\mathrm{pH}$ towards neutral was noticed in seed bio-priming treatments (7.1 to 7.3). Second season data showed that the highest $\mathrm{pH}$ was noticed in control, 70\% RDF and RDF (7.5), while the lowest was in treatment supplied with $80 \%$ RDF along with bio-priming (7.2). Pooled revealed that the highest $\mathrm{pH}$ value was in control (7.5) while the minimum was noticed in $T_{7}(7.2)$. Soil physicochemical properties such as soil reaction, electrical conductivity, and cation exchange capacity play a vital role in the chemistry and fertility of the soil (Neina 2019). Soil reaction extensively influences soil physical, chemical, and biological properties that determine crop growth and yield (Minasny et al. 2012; Neina 2019). Similar results were found with Trichoderma inoculation in Lolium (Song et al. 2015), in Miscanthus, Salix, Phalaris and Panicum (Kacprzak et al. 2014), which might be due 
to the ability of Trichoderma to produce organic acids such as gluconic acid, fumaric acid and citric acid (Wang and Chen 2009; Song et al. 2015). In pearl millet and wheat crop, inoculation of cyanobacterial bio-fertilizer resulted in a decrease in soil $\mathrm{pH}$ (Nisha et al. 2007).

\section{Electrical conductivity}

In the current experiment, pooled data showed that the range is between $0.34 \mathrm{dSm}^{-1}$ and $0.43 \mathrm{dSm}$ ${ }^{1}$ (Fig. 2). There is no specific trend in EC values with imposed treatments, however, in pooled data, maximum conductivity was observed in treatment supplied with $70 \%$ RDF $\left(0.43 \mathrm{dSm}^{-1}\right)$ while the minimum was noticed in treatment supplied with $70 \%$ RDF along with bio-priming $\left(0.34 \mathrm{dSm}^{-1}\right)$. Soil cation exchange capacity is the ability of soil to hold and exchange mineral elements. Soil chemical properties can be assessed by cation exchange capacity (Saidi 2012).

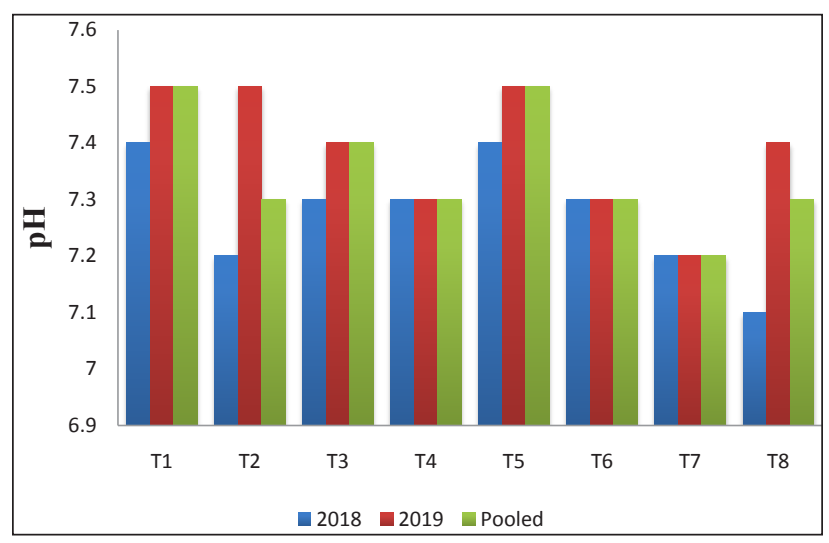

Fig. 2: Effect of different treatments on soil reaction

\section{Cation Exchange Capacity}

Cation exchange capacity during the first season experiment ranged between 22.73 and $24.11 \mathrm{cmol}$ $(\mathrm{p}+) \mathrm{kg}^{-1}$. Minimum value was noticed in control, wherethe CEC of treatments supplied with $70 \%$ $\mathrm{RDF}+$ bio-priming and 80\% RDF + seed bio-priming were 5.71 and $6.07 \%$ higher, respectively. In second season experiment treatments supplied with $80 \%$ RDF + bio-priming, 80\% RDF + bio-priming and 90\% RDF + seed bio-priming were 3.7, 1 and 3.02\% higher values were noticed (Fig. 3). An increase in soil CEC with Azotobacter was noticed in Solanum (Demir, 2020) whereas in pearl millet and wheat crop, inoculation of cyanobacterial bio-fertilizer showed a slight increase in soil CEC (Nisha et al. 2007). According to a study on Miscanthus, Salix, Phalaris, and Panicum, there is no effect of Trichoderma on soil CEC (Kacprzak et al. 2014).

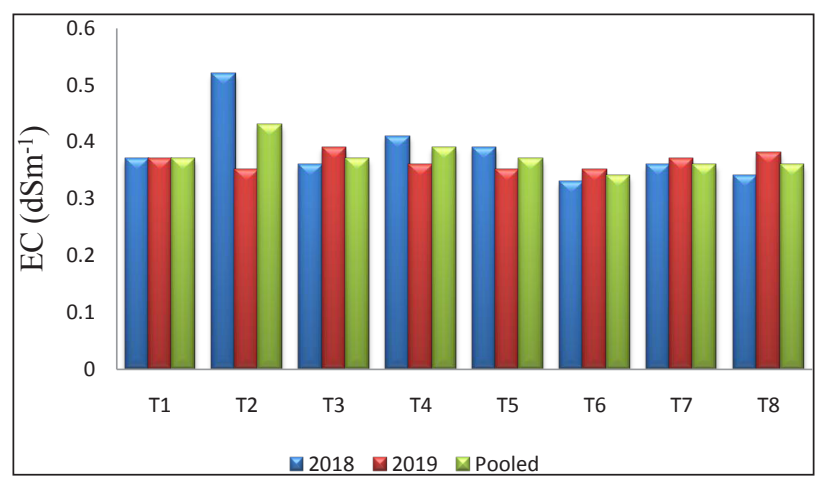

Fig. 3: Effect of seed bio-priming on soil EC $\left(\mathrm{dSm}^{-1}\right)$

\section{Soil available nitrogen}

Soil available nitrogen content varied significantly with different imposed treatments in both the seasons (Fig. 4) and ranged from 205 to $244 \mathrm{~kg} \mathrm{ha}^{-1}$ on pooled bases. The highest value was recorded in treatment supplied with $80 \% \mathrm{RDF}+$ bio-priming with Trichoderma asperellum, which was significantly superior to control (205 kg ha-1), 70\% RDF (225 kg $\mathrm{ha}^{-1}$ ), and significantly superior to the rest of the treatments.

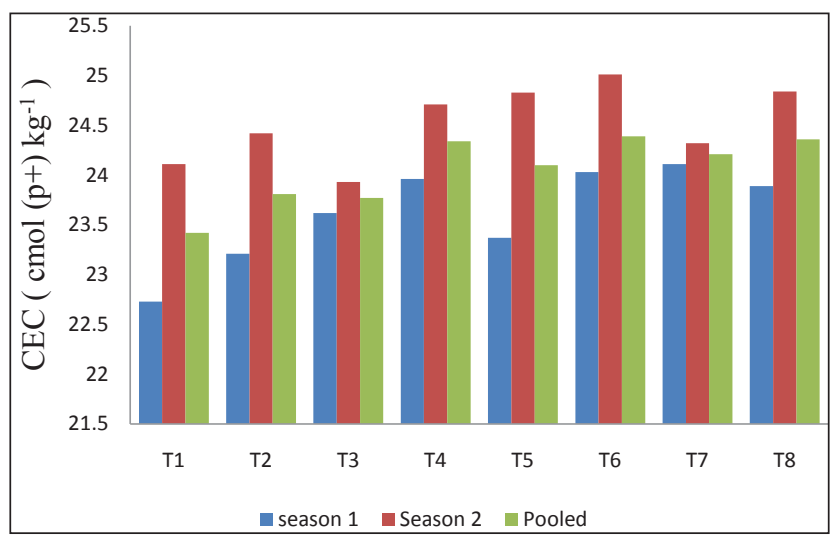

Fig. 4: Effect of different imposed treatments on soil CEC $\left(\mathrm{cmol}\left(\mathrm{p}^{+}\right) \mathrm{kg}^{-1}\right)$

The highest available soil nitrogen in both the seasons (2018 and 2019) was recorded in the treatment $\mathrm{T}_{7}(80 \% \mathrm{RDF}+$ bio-priming with Trichoderma asperellum), i.e., 240 and $249 \mathrm{~kg} \mathrm{ha}^{-1}$ respectively that was at par with $\mathrm{T}_{3}-\mathrm{T}_{6}$ and $\mathrm{T}_{8}$ treatments. Enhance in soil available nutrients was due to the ability of Trichoderma to solubilize soil nutrients (Yadav et al. 2009; Kapri and Tewari 2010). Inoculation of Trichoderma spp. enhanced soil available nitrogen 
in Pinus (Halifu et al. 2019), in pepper (Liu et al. 2020), soil available phosphorus in maize (Mercl et al. 2020), sugarcane (Yadav et al. 2009), in Lolium perenne (Song et al. 2014), in alfalfa (Zhang et al., 2019), cassava (Hridya and Byju 2014), sugarcane (Thakur et al. 2010).

\section{Soil available phosphorus}

Available soil phosphorus content was ranged between 15.5 and $24.07 \mathrm{~kg} \mathrm{ha}^{-1}$ in pooled analysis (Fig. 5). Pots received 80\%, 90\% RDF along with biopriming showed maximum available phosphorus content $\left(23.15,23.32 \mathrm{~kg} \mathrm{ha}^{-1}\right)$ that was comparable to $100 \%$ RDF treatment $\left(22.58 \mathrm{~kg} \mathrm{ha}^{-1}\right)$ and significantly superior to the rest of the treatments in the first season.

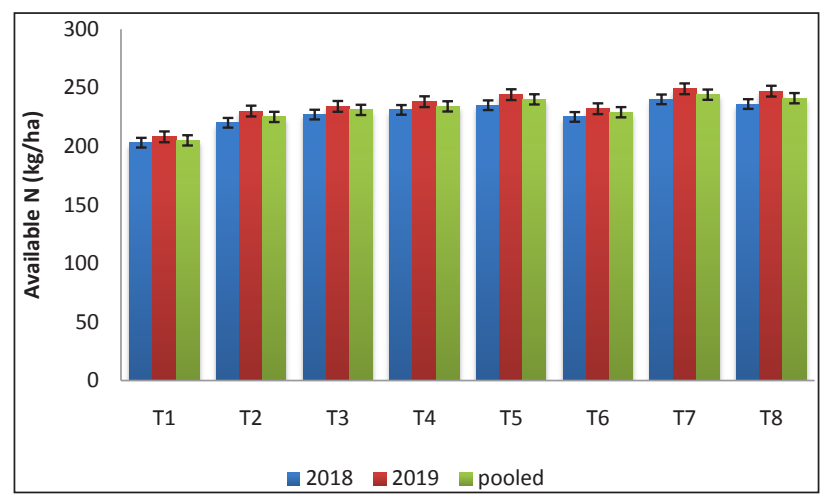

Fig. 5: Treatments impact on soil available nitrogen $\left(\mathrm{kg} \mathrm{ha}^{-1}\right)$

The highest available $\mathrm{P}$ at harvest of sunflower in the second season experiment was noticed in $\mathrm{T}_{8}(90 \% \mathrm{RDF}+$ bio-priming with Trichoderma asperellum) (24.82 kg ha-1) that was found at par with the treatments $\mathrm{T}_{3}$ to $\mathrm{T}_{7}\left(21.33\right.$ to $\left.24.14 \mathrm{~kg} \mathrm{ha}^{-1}\right)$ and significantly superior to control (16.62 $\left.\mathrm{kg} \mathrm{ha}^{-1}\right)$ and $\mathrm{T}_{2}\left(20.45 \mathrm{~kg} \mathrm{ha}^{-1}\right)$. Phosphorus solubilization of a substrate (calcium phosphate) by Trichoderma spp. was ranged between $51.7 \%$ and $90.3 \%$ after 10 days incubation (Bononi et al. 2020). Inoculation of Trichoderma spp. enhanced soil available phosphorus in Pinus (Halifu et al. 2019), in pepper (Liu et al. 2020), soil available phosphorus in maize (Mercl et al. 2020), sugarcane (Yadav et al. 2009), in Lolium perenne (Song et al. 2014), in alfalfa (Zhang et al. 2019), cassava (Hridya and Byju 2014), sugarcane (Thakur et al. 2010).

\section{Soil available potassium}

Available soil potassium content at harvest was ranged from 212 to $247 \mathrm{~kg} \mathrm{ha}^{-1}$ according to pooled data (Fig. 6) in which the highest was found in the treatment supplied with $90 \%$ RDF + bio-priming with Trichoderma asperellum (247 kg ha-1) comparable to the treatments $T_{2}$ to $T_{7}$ and all fertilized treatments except $T_{2}$ were significantly superior to control. The highest available potassium content in both first and second season crop was found in $\mathrm{T}_{8}$ (246 and $248 \mathrm{~kg} \mathrm{ha}^{-1}$ respectively) that was comparable to the treatments $\mathrm{T}_{2}$ to $\mathrm{T}_{7}\left(239\right.$ to $247 \mathrm{~kg} \mathrm{ha}^{-1}$ and 233 to $246 \mathrm{~kg} \mathrm{ha}^{-1}$ respectively) and significantly superior to control. Enhance in soil available nutrients was due to the ability of Trichoderma to solubilize soil nutrients (Yadav et al., 2009, Kapri and Tewari, 2010). Available soil potassium with Trichoderma inoculation was recorded in alfalfa (Zhang et al., 2019), cassava (Hridya and Byju, 2014), sugarcane (Thakur et al. 2010).

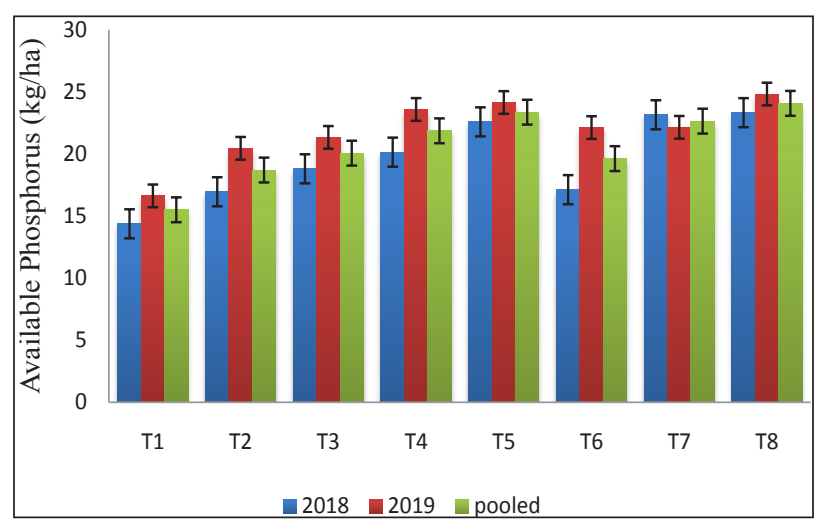

Fig. 6: Effect of treatment combinations on soil available phosphorus $\left(\mathrm{kg} \mathrm{ha}^{-1}\right)$

\section{Correlation}

Correlation among soil $\mathrm{pH}, \mathrm{EC}, \mathrm{CEC}$, available N, $\mathrm{P}$, and $\mathrm{K}$ was presented in Fig. 7.

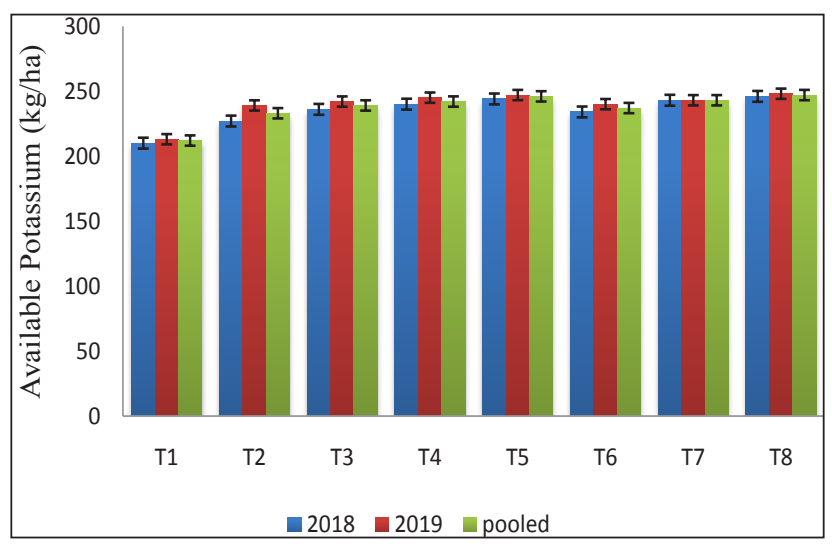

Fig. 7: Influence of seed bio-priming on soil available potassium content $\left(\mathrm{kg} \mathrm{ha}^{-1}\right)$ 
Normal curve of each parameter is depicted. The correlation coefficient ranged from -0.611 to 0.971 . Soil reaction and electrical conductivity showed a negative correlation with all studied parameters viz., CEC, available nitrogen, phosphorus, and potassium ranged from -0.611 to -0.025 with $\mathrm{pH}$ and -0.359 to -0.148 with EC. Cation Exchange Capacity was positively correlated with Soil available nitrogen (0.779), phosphorus (0.777) and potassium (0.803). Soil nitrogen strongly correlated with soil phosphorus (0.959) and potassium (0.971), while phosphorus and potassium were strongly correlated with each other (0.949).

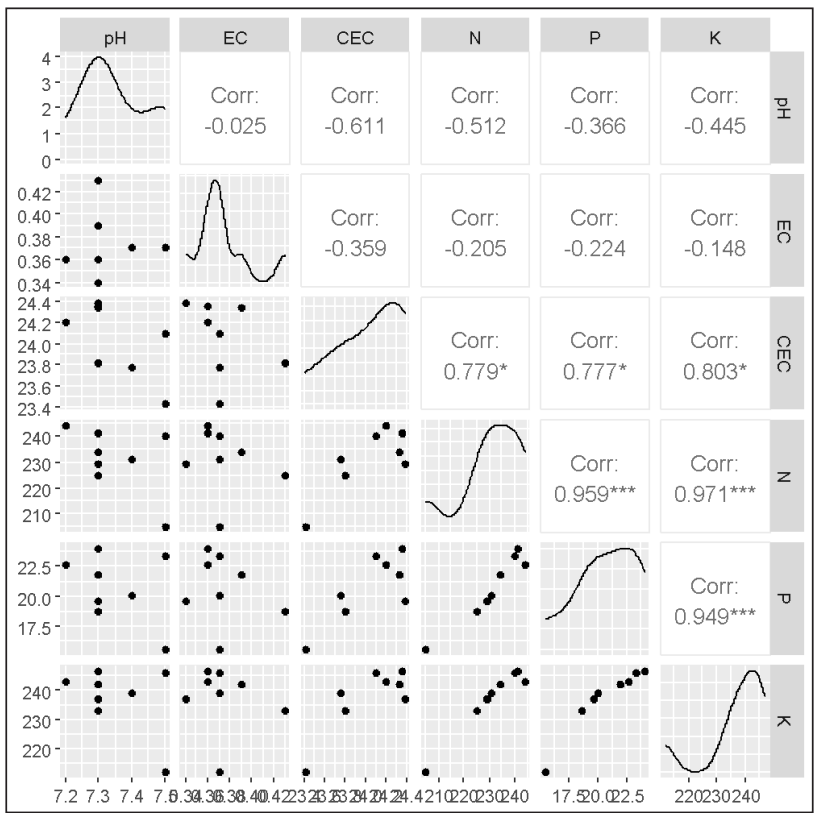

Fig. 8: Correlation among soil chemical parameters. Abbreviations: pH- Soil reaction, EC- Electrical Conductivity, CEC- Cation Exchange Capacity, N- Soil available nitrogen, P-Soil available phosphorus, K- Soil available potassium.

\section{CONCLUSION}

The current experiment revealed the gradual improvement in soil chemical properties with biopriming intervention. All the treatments which received Trichoderma asperellum through seed biopriming gave positive results with respect to soil reaction, electrical conductivity, cation exchange capacity, soil available N, P, and $\mathrm{K}$. Integration of seed bio-priming with chemical fertilization was performed well as compared to a recommended dose of fertilization. Bio-priming treatments are effective for improving soil chemical properties that reduced the crop requirement of agrochemicals as well as minimize the negative impacts of intensive agricultural practices. Practicing seed bio-priming techniques is feasible, eco-friendly, economical, and helpful for plant growth.

\section{REFERENCES}

Arriaga, F. J., Guzman, J. and Lowery, B. 2017. Conventional agricultural production systems and soil functions. In Soil health and intensification of agroecosytems (pp. 109-125). Academic Press.

Aulakh, M.S. and Sidhu, G.S. 2015. Soil degradation in India: Causes, major threats, and management options. In MARCO symposium (pp. 151-156).

Bononi, L., Chiaramonte, J.B., Pansa, C.C., Moitinho, M.A. and Melo, I.S. 2020. Phosphorus-solubilizing Trichoderma spp. from Amazon soils improve soybean plant growth. Sci. Rep., 10(1): 1-13.

Bower, C.A., Reitemeier, R.F and Fireman, M. 1952. Exchangeable cations analysis of saline and alkali soils. Soil Sci., 73: 251-261.

Demir, Z. 2020. Effects of microbial bio-fertilizers on soil physicochemical properties under different soil water regimes in greenhouse grown eggplant (Solanum Melongena L.). Commun. Soil Sci. Plan., 51(14): 1888-1903.

Halifu, S., Deng, X., Song, X. and Song, R. 2019. Effects of two Trichoderma strains on plant growth, rhizosphere soil nutrients, and fungal community of Pinus sylvestris var. mongolica annual seedlings. Forests, 10(9): 758.

Hridya, A.C. and Byju, G. 2014. Effect of chemical fertilizers and microbial inoculations on soil properties in cassava (Manihot esculenta) growing Vertisols of Tamil Nadu. Indian J. Agric. Sci., 84(7): 860-6.

Jackson, M.L. 1973. Soil chemical analysis. Prentice Hall of India Private Ltd., New Delhi, pp. 134-182.

Kacprzak, M.J., Rosikon, K., Fijalkowski, K. and Grobelak, A. 2014. The effect of Trichoderma on heavy metal mobility and uptake by Miscanthus giganteus, Salix sp., Phalaris arundinacea, and Panicum virgatum. Appl. Environ. Soil Sci., 2014.

Kapri, A. and Tewari, L. 2010. Phosphate solubilization potential and phosphatase activity of rhizospheric Trichoderma spp. Braz. J. Microbiol., 41(3): 787-795.

Liu, Q., Meng, X., Li, T., Raza, W., Liu, D. and Shen, Q. 2020. The growth promotion of peppers (Capsicum annuum L.) by Trichoderma guizhouense NJAU4742-based biological organic fertilizer: possible role of increasing nutrient availabilities. Microorganisms, 8(9): 1296.

Mercl, F., García-Sánchez, M., Kulhánek, M., Košnář, Z., Száková, J. and Tlustoš, P. 2020. Improved phosphorus fertilisation efficiency of wood ash by fungal strains Penicillium sp. PK112 and Trichoderma harzianum OMG08 on acidic soil. Appl. Soil Ecol., 147: 103360.

Minasny, B., Hong, S.Y., Hartemink, A.E., Kim, Y.H. and Kang, S.S. 2016. "Soil pH increase under paddy in South Korea between 2000 and 2012," Agric. Ecosyst. Environ., 221: 205-213. 
Muhr, G.R., Datta, N.P., Sankarasubramoney, H., Leley, V.K and Dunabha, R.L. 1965. Soil testing in India. $2^{\text {nd }}$ ed, USAID - Mission to India, New Delhi.

Neina, D. 2019. The role of soil $\mathrm{pH}$ in plant nutrition and soil remediation. Appl. Environ. Soil Sci., 2019.

Nisha, R., Kaushik, A. and Kaushik, C.P. 2007. Effect of indigenous cyanobacterial application on structural stability and productivity of an organically poor semi-arid soil. Geoderma, 138(1-2): 49-56.

Rakshit, A., Sunita, K., Pal, S., Singh, A. and Singh, H.B. 2015. Bio-priming mediated nutrient use efficiency of crop species. Nutrient use efficiency: from basics to advances, pp. 181-191.

Rakshit, A. 2019. Impact assessment of bio priming mediated nutrient use efficiency for climate resilient agriculture. In Climate Change and Agriculture in India: Impact and Adaptation (pp. 57-68). Springer, Cham.

Rocha, I., Ma, Y., Souza-Alonso, P., Vosátka, M., Freitas, H. and Oliveira, R.S. 2019. Seed coating: a tool for delivering beneficial microbes to agricultural crops. Front. Plan. Sci., 10: 1357.

Saidi, D. 2012. Importance and role of cation exchange capacity on the physicals properties of the Cheliff saline soils (Algeria). Procedia Eng., 33: 435-449.

Sarkar, D., Ray, S., Singh, N.K., Rakshit, A. and Singh, H.B. 2018. Seed priming with bio-inoculants triggers nutritional enrichment in vegetables: a review. Int. J. Agric. Environ. Biotechnol., pp. 727-35.

Sarkar, D. and Rakshit, A. 2021. Bio-priming in combination with mineral fertilizer improves nutritional quality and yield of red cabbage under Middle Gangetic Plains, India. Sci. Hortic., 283: 110075.

Singh, V., Maharshi, A., Singh, D.P., Upadhyay, R.S., Sarma, B.K. and Singh, H.B. 2018. Role of microbial seed priming and microbial phytohormone in modulating growth promotion and defense responses in plants. In Advances in Seed Priming (pp. 115-126). Springer, Singapore.

Song, N., Ma, Y., Zhao, Y. and Tang, S. 2014. Elevated ambient carbon dioxide and Trichoderma inoculum could enhance cadmium uptake of Lolium perenne explained by changes of soil $\mathrm{pH}$, cadmium availability and microbial biomass. Appl. Soil Ecol., 85: 56-64.
Song, N., Ma, Y., Zhao, Y. and Tang, S. 2015. Elevated ambient carbon dioxide and Trichoderma inoculum could enhance cadmium uptake of Lolium perenne explained by changes of soil $\mathrm{pH}$, cadmium availability and microbial biomass. Appl. Soil Ecol., 85: 56-64.

Subbiah, B.V. and Asija, C.L. 1956. A rapid procedure for the estimation of available nitrogen in soils. Curr. Sci., 25: 259-260.

Thakur, S.K., Jha, C.K., Kumari, G. and Singh, V.P. 2010. Effect of Trichoderma inoculated trash, nitrogen level and biofertilizer on performance of sugarcane (Saccharum officinarum) in calcareous soils of Bihar. Indian J. Agron., 55(4): 308-311.

Visconti, F. and de Paz, J.M. 2016. Electrical conductivity measurements in agriculture: The assessment of soil salinity. New trends and Dev. Metrology, 1: 99-126.

Wang, J. and Chen, C. 2009. Biosorbents for heavy metals removal and their future. Biotechnol. Adv., 27: 195-226.

Watanabe, F.S. and Olsen, S.R. 1954. Test for ascorbic acid method for determining phosphorus in water and sodium bicarbonate extracts of soil. Soil Sci. Soc. Am. J., 29: 677-678.

Yadav, R.L., Shukla, S.K., Suman, A. and Singh, P.N. 2009. Trichoderma inoculation and trash management effects on soil microbial biomass, soil respiration, nutrient uptake and yield of ratoon sugarcane under subtropical conditions. Biol. Fertil. Soils, 45(5): 461-468.

Zhang, F., Xu, X., Huo, Y. and Xiao, Y. 2019. Trichodermainoculation and mowing synergistically altered soil available nutrients, rhizosphere chemical compounds and soil microbial community, potentially driving alfalfa growth. Front. Microbiol., 9: 3241.

Zhang, L., Yan, C., Guo, Q., Zhang, J. and Ruiz-Menjivar, J. 2018. The impact of agricultural chemical inputs on environment: global evidence from informetrics analysis and visualization. Int. J. Low-Carbon Technol., 13(4): 338352. 